\title{
Electronic Tax Filing in Mauritius: Insights into Factors Leading to Technology Adoption
}

\author{
Hemant B. Chittoo and RoopashneeDhotah \\ (University of Technology, Mauritius)
}

\begin{abstract}
The electronic tax filing system is one of the important and value-added e-government services in Mauritius. It is important to understand the factors that influence the taxpayers to make us of electronic tax filing system, given the great investment that it implies. This study investigated the factors that led to the behavioural intention to use electronic tax filing system among taxpayers. To examine these perceptions, an extended version of Technology Acceptance Model (TAM) has been used. It consists of three constructs, namely, perceived ease of use (PEOU), perceived usefulness (PU), and perceived risk (PR). Questionnaires were distributed to 140 respondents. Based on the results obtained from the study, both perceived ease of use and perceived usefulness were found to significantly influence behavioural intention. However, the study reveals that there is no significant association between perceived risk and the other constructs; perceived usefulness, perceived ease of use and behavioural intention.
\end{abstract}

Key words and Terms:e-filing in Mauritius, perceived ease of use, perceived usefulness, perceived risk, technology acceptance model.

\section{INTRODUCTION}

Many countries around the world have realised the benefits of e-government. They are ambitious in providing a range of services online. E-government services benefit the country by reducing costs, improving services for citizens, and increasing effectiveness and efficiency. The most well-known online service provided by the government of Mauritius is the electronic tax filing. Currently there are two methods of tax filing in Mauritius: manual filing and electronic filing. The manual filing consists of performing complex calculation and fill out standard printed form obtained from the Mauritius Revenue Authority (MRA). Once the form has been filled, it has to be submitted over the counter or by postal mail at the MRA. The taxpayers have to make sure that there is no error through the manual method of filing. The traditional method is very laborious and time consuming as the tax collection department has to enter each taxpayers' data into the company's computer system.

The electronic tax filing system was introduced in 2007 by the MRA. The taxpayers need to fill their tax forms through the internet. They just need to log in on the website of the MRA to have access to the tax form. The taxpayers are guided on the correct information to input and the system does necessary calculations based on the information provided. Filing tax online is more efficient for the MRA as it reduces computation errors and is quicker in collecting taxes. Moreover, taxpayers benefit from e-filing since it saves time. There is no need for them to go to the tax office to submit their forms. Another important aspect is that the e-filing system speeds up tax refunds.

Obviously, the e-filing system has the potential to satisfy both taxpayers and tax collectors. But this can only be said if it is actually being used by the citizens of the country. The Government of Mauritius wishes to maximize the number of eligible taxpayers to adopt the system, even though the people still have the option to choose between manually filing their tax returns or to do so electronically.

Yet, to fully benefit from electronic tax filing, it does not only depend on the implementation of this online service but also on the perception of the taxpayers. The aim of this research is to understand the perception of the taxpayers about this new technology, and what factors can influence their intention to adopt the electronic tax filing system or to revert to manual filing. For this study, the Technology Acceptance Model (TAM) has been used to explain the relationships between perceptions and technology use. Three key determinants were used: perceived ease of use (PEOU), perceived usefulness (PU), and perceived risk (PR).

\section{LITERATURE REVIEW}

There exists different definitions for the term e-government and the differences reflect the different priorities in the government strategies. According to Moon and Norris (2005, p.43), e-government is 'a means of delivering government information and services'. Fang (2002) defined e-government as a way for government to use the most innovative information and communication technologies, particularly web-based internet 
applications to provide citizens and businesses with more convenient access to government information and services, to improve the quality of the services, and to provide greater opportunities to participate in democratic institution and processes. E-government policies have been adopted around the world to simplify interactions between different government agencies, employees, citizens and businesses sectors. These different types of egovernment are; Government to Citizens (G2C), Government to Business (G2B), Government to Employees (G2E) and Government to Government (G2G).

The benefits of e-governance are so numerous that developing countries like Mauritius have no choice than to transform their governance systems into e-governance (Chittoo et al., 2008). E-government builds trust between the government and the citizens, it also improves efficiency, accuracy, and reliability in processing large quantities of data. About 66 e-services of various ministries and departments are available online for the citizens of Mauritius to interact with the government anytime, anywhere and in real-time.

The electronic tax filing or e-filing system, is a system of filing tax documents to revenue service electronically, often done online. Instead of going to the tax collection office to fill in the tax forms and doing payments, the taxpayer can do all this simply through the internet. Many studies have concluded that e-filing has greatly enhances tax services. Mauritius has moved to the adoption of e-filing of taxes with a towering of $92 \%$ of the total number of tax filings received online in 2014. The MRA has registered 123,000 electronic submissions in 2015. The number of e-filers has constantly been improved from 1,500 in 2007 to 117,000 in 2013, and finally 123,000 in 2015. E-filing is environmental friendly, there is negligible paper wastage. Electronic tax filing improves efficiency by reducing computation errors. Moreover, the e-filing system benefits taxpayers since they save time by filing their tax online and receive their tax returns electronically.

The technology acceptance model (TAM) developed by Davis (1989) is one of the most popular and influential models in studying the determinants of IT usage and acceptance. TAM is an adaption of the Theory of Reasoned Action (TRA) proposed by Ajzen in 1980. It was designed to help to explain why users accept and use technology, and what influent factors are involved in these processes. TAM uses two perceptions, 'perceived usefulness' (PU) and 'perceived ease of use' (PEOU). Perceived usefulness (PU) refers to 'the degree to which a person believes that using a particular system would enhance his/her job performance', (Davis, 1989). Perceived ease of use (PEOU) is defined as 'the degree to which a person believes that using a particular system would be free from effort', (Davis, 1989). Studies based on TAM have always shown positive relationship between perceived usefulness and perceived ease of use. Prior studies have shown significant effects of perceived usefulness (PU) and perceived ease of use(PEOU) on behavioural intention (BI). Fu et al. (2006) found that behavioural intention is greatly driven by perceived usefulness, and other findings showed that perceived usefulness is influenced by perceived ease of use.

Perceived risk (PR) is defined as 'the expectation of losses associated with purchase and acts as an inhibitor to purchasing behaviour' (Peter \& Ryan, 1976). The definition of perceived risk has changed since online transactions have become popular. Another definition would be 'a fear of losing personal information and fear of being monitored on the internet', (Kumar Mukerjiet al., 2007). Perceived risk has two facets, namely privacy risk and performance risk. Privacy risk refers to the safeguard of the data, while performance risk refers to the possibility of system failure. According to previous studies, perceived risk (PR) affects behavioural intention (BI). Perceived risk in these studies only measure the effect of overall risk on behavioural intention to use or adopt electronic tax filing. Fu et al. (2006) suggest that perceived risk significantly influence the behavioural intention (BI) of taxpayers who file their tax electronically.

\section{RESEARCH METHODOLOGY}

Based on different literatures and theories, the present study examines the relationships between perceived ease of use, perceived usefulness, perceived risk and behavioural intention of using tax e-filing system in Mauritius. The following hypotheses were formulated for the four constructs.

- $\mathrm{H}_{1}$ : Perceived usefulness (PU)will have a positive effect on behavioural intention (BI) to use electronic tax filing system.

- $\mathrm{H}_{2}$ : Perceived ease of use (PEOU) will have a positive effect on behavioural intention (BI) to use electronic tax filing system.

- $\mathrm{H}_{3}$ : Perceived ease of use (PEOU) will have a positive effect on perceived usefulness (PU) of electronic tax filing system.

If taxpayers perceived the system as useful and easy to use, they evaluate the system positively, which leads to adoption. Perceived risk in this study is defined as taxpayer's perception on the reliability of system and safeguard of personal tax information. However, the following hypothesis on the perceived risk (PR) construct were made.

- $\mathrm{H}_{4}$ : Perceived risk (PR) will have a negative effect on behavioural intention (BI) to use electronic tax filing system. 
- $\mathrm{H}_{5}$ : Perceived risk (PR) will have a negative effect on perceived usefulness (PU) of electronic tax filing system.

If the system is perceived as easy to use, perceived ease of use (PEOU) is considered as a risk-reducing factor, which leads to the following hypothesis on perceived risk (PR).

- $\quad \mathrm{H}_{6}$ : Perceived ease of use (PEOU) will have a negative effect on perceived risk (PR) of electronic tax filing system.

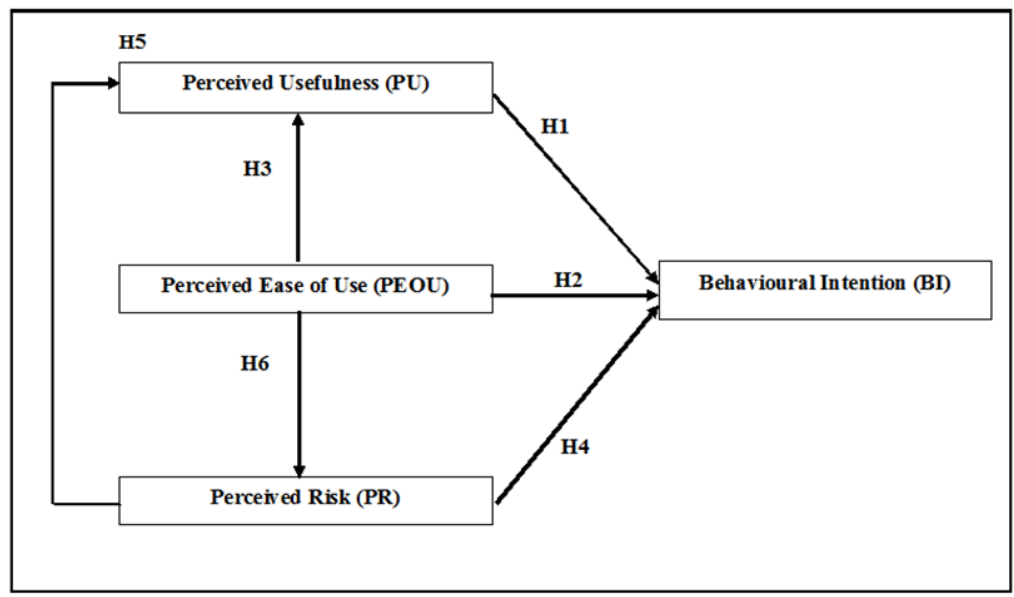

Figure 1 Research Model

In this study, convenience sampling method was used. A sample size of 140 respondents was used from two different departments of two different companies respectively. The sample size was calculated using the Slovin's Formula with a population size of 200 respondents and 5\% level of precision. The respondents were mainly salaried taxpayers as they were the ones who were eligible for e-filing.

Questionnaire was the main method used to collect primary data. A Likert scale with nine levels of possible answer was utilised. The questionnaire was divided into two sections. Section A contained questions on the background of the respondents and questions about their computer and internet experience. Section B contained statements of the TAM model which measured the taxpayers' perception on the e-filing system and their behavioural intention to adopt. Statistical analysis was performed and Linear Regression Analysis were performed to gain insight in the statistical relationships between the variables.

\section{DATA ANALYSIS}

From a total of 140 respondents: $96(68.6 \%)$ were male and $44(31.4 \%)$ were femalesalaried taxpayers. The survey also showed that a majority of $45(32.1 \%)$ repondents are aged 25 to 35 years old, $43(30.7 \%)$ of them were aged 36 to 45 years old, $23(16.4 \%)$ out of 140 respondents were in the age group 46 to 55 years and 29 $(20.7 \%)$ were above 55 years old. There we no taxpayers less than 25 years old.

The Cronbach's coefficient alpha for the four constructs which comprised of sixteen items are shown in the table below. Since all the alpha coefficients have values above 0.700, it indicates that the developed scale of this study is highly reliable and acceptable.

\begin{tabular}{|l|l|l|}
\hline Constructs & Items & Cronbach's $\boldsymbol{\alpha}$ \\
\hline Perceived Usefulness (PU) & 4 & 0.977 \\
\hline Perceived Ease Of Use (PEOU) & 4 & 0.960 \\
\hline Perceived Risk (PR) & 4 & 0.972 \\
\hline Behavioural Intention (BI) & 4 & 0.888 \\
\hline
\end{tabular}

Table 1 Results of Reliability Test 
The following findings indicate that most of the participants have very good computer and internet experiences and knowledge.

\begin{tabular}{|l|l|l|}
\hline Computer Experience & Frequency & Percentage \\
\hline None & 0 & 0.0 \\
\hline $1-3$ years & 16 & 11.4 \\
\hline 4-6 years & 10 & 7.1 \\
\hline 7-9 years & 6 & 4.3 \\
\hline 10 years or above & 108 & 77.1 \\
\hline & & \\
\hline Internet Experience & & \\
\hline None & 0 & 0.0 \\
\hline $1-3$ years & 23 & 16.4 \\
\hline 4-6 years & 8 & 5.7 \\
\hline 7-9 years & 14 & 10.0 \\
\hline 10 years or above & 95 & 67.9 \\
\hline
\end{tabular}

Table 2 Computer and Internet Experience of Respondents

From the results obtained from the linear regression analysis perceived usefulness (PU) and behavioural intention (BI)were found to have a strong and positive relationship $(\beta=0.90$, $p$-value $<0.05)$. As people see that e-filing is useful and enhance their job performance, their intention to use and adopt the system increase. However, perceived ease of use (PEOU) has a stronger relationship $(\beta=0.94$, $p$-value $<0.05)$ with behavioural intention (BI). The easier the system is to use, the greater the intention to adopt or use e-filing.

Previous research had showed that there is a positive relationship between perceived ease of use (PEOU) and perceived usefulness (PU) with the acceptance of information technology (Venkatesh\& Davis, 2000). This relationship is interpreted as the easier the use of the system, the more useful it is perceived to be. In the present study, the finding also confirm this relationship $(\beta=0.92$, $p$-value $<0.05)$. In other words, taxpayers perceived the electronic tax filing system is easy to learn and easy to use which make taxpayers to perceive the system as useful. Another finding from this study shows that there is a negative relationship between perceived ease of use (PEOU) and perceived risk (PR), but this relationship was not significant $(\beta=0.92, p$-value $>0.05)$. A possible reason that can explain this non-significant path could be because there is a large number of young taxpayers in this survey. About $62.8 \%$ of the respondents are aged between 25 years old and 45 years old. They are more computer literate and more comfortable with internet based transactions. Another reason could be the fact that internet has proved that it is trustworthy through its improved security norms. As such, taxpayers find ease of use as a risk reducing factor.However, according to the results of this study, perceived risk (PR) has a negative effect on the constructs behavioural intention (BI) with $\beta=-0.04$, and perceived usefulness (PU) of tax e-filing system with $\beta=-0.03$, but both paths were not significant. There was no correlation ( $\mathrm{p}$-value $>0.05$ ) between perceived risk (PR) and the two constructs perceived usefulness (PU) and behavioural intention (BI). This result is in contrast with earlier research on the adoption and usage of electronic tax filing system. Earlier research found that perceived risk (PR) was negatively related to e-filing usage and adoption. That is, the increase feeling of risk and anxiety would cause the taxpayers to devalue perceived usefulness of tax e-filing system. Taxpayers who perceived the security and reliability of the system to be lower, would be less likely to use the system. Also, results indicate no correlation between perceived ease of use (PEOU) and perceived risk (PR). But, perceived ease of use (PEOU) does has a negative effect $(\beta=-0.12)$ on perceived risk $(\mathrm{PR})$.

\begin{tabular}{|l|l|}
\hline Hypotheses & Results \\
\hline $\mathbf{H}_{\mathbf{1}}:$ Perceived usefulness (PU) will have positive effect on behavioural intention & Supported \\
$(\mathrm{BI})$ to use electronic tax filing system. & \\
\hline $\mathbf{H}_{\mathbf{2}}$ : Perceived ease of use (PEOU) will have a positive effect on behavioural & Supported \\
intention (BI) to use electronic tax filing system. & \\
\hline $\begin{array}{l}\mathbf{H}_{3}: \text { Perceived ease of use (PEOU) will have a positive effect on perceived } \\
\text { usefulness (PU) of electronic tax filing system. }\end{array}$ & Supported \\
\hline $\begin{array}{l}\mathbf{H}_{4}: \text { Perceived risk (PR) will have a negative effect on behavioural intention (BI) to } \\
\text { use electronic tax filing system. }\end{array}$ & Rejected \\
\hline $\begin{array}{l}\mathbf{H}_{5}: \text { Perceived risk (PR) will have a negative effect on perceived usefulness (PU) of } \\
\text { electronic tax filing system. }\end{array}$ & Rejected \\
\hline $\begin{array}{l}\mathbf{H}_{6}: \text { Perceived ease of use (PEOU) will have a negative effect on perceived risk } \\
\text { (PR) of electronic tax filing system. }\end{array}$ & Rejected \\
\hline
\end{tabular}

Table 3 Results for Hypothesis Testing 


\section{CONCLUSIONS}

The study provides further evidence with respect to the variables of the proposed TAM research model: perceived ease of use (PEOU), perceived usefulness (PU), perceived risk (PR), and their relationship with the dependent variable, behavioural intention (BI). The findings of this study are as follow:

- Both perceived ease of use (PU) and perceived usefulness (PU) have a positive and significant relationship with the behavioural intention (BI) to use electronic tax filing.

- Perceived ease of use $(\beta=0.94)$ proved to be a slightly stronger predictor to behavioural intention than perceived usefulness $(\beta=0.90)$

- Perceived risk (PR) has negative and non-significant relationship with both behavioural intention and perceived usefulness

- Perceived ease of use has a negative and non-significant relationship with perceived risk

- Perceived risk has no influence on the adoption or usage of electronic tax filing system.

This study, however, comprises some limitations. First, it is difficult to generalise the findings since a convenience sampling method was used. A larger and random sample would have been much better for generalisation. Second, the data obtained are only quantitative data which limits the findings. Triangulation of data is a way of assuring validity and coherence of data. Besides, there exists many other factors that could influence the behavioural intention to use e-filing system. There are more opportunities for further research by broadening the TAM model, like using the UTAUT model to look for other elements.

\section{REFERENCES}

[1] AJZEN, I., and FISHBEIN, M., 1980. Understanding Attitudes and Predicting Social Behaviour, Eaglewood Cliffs, NJ: Prentice-Hall.

[2] CHITTOO, H., RAMESSUR-SEENARAIN, T., DUBARRY, R., 2008. The Challenges of Implementing Local e-Governance in Mauritius: Case of Revenue Management System, pp. 89-100, LOGIN-AFRICAIDRC (Canada), CAFRAD, Cairo University (2008) Conference Proceedings, Cairo, Egypt.5-6 June 2008..

[3] DAVIS, F.D., BAGOZZI, R.P., and WARSHAW, P.R., 1989. User Acceptance of Computer technology: A Comparison of Two Theoretical Models. Management Science [online], 35(8), Available from: http://home.business.utah.edu.

[4] Explorable, 2009. Sample Size [online], Available from: http://explorable.com.

[5] FANG, Z., 2002. E-government in digital era: Concept, practice, and development. International Journal of the Computer, the Internet and Management, 10(2), pp. 1-22.

[6] FU, J.R., FARN, C.K., and CHAO, W.P., 2005. Acceptance of electronic tax filing: A study of taxpayer intentions. Information \& Management [online], Available from: www.sciencedirect.com.

[7] Global Information Technology Report 2015. World Economic Forum [online], Available from: http://reports.weforum.org.

[8] JOSHI. A., 2008. Advantage of E-governance. E-Governance in India [online], Available from: www.google.com.

[9] KUMAR, V., MUKERJI, B., BUTT, I., \& PERSAUD, A., 2007. Factors for successful e-government adoption: A conceptual framework. Electronic Journal of e-Government, 5(1), pp. 63-76.

[10] Mauritius Internet Users. Internet live stats [online]. Available from: www.internetlivestats.com.

[11] NCB, Services of GOC. Mauritius: Republic of Mauritius portal.

[12] NEUMAN, W., 2006. Social Research Methods: Qualitative and Quantitative approaches (6 ${ }^{\text {th }}$ Ed.). Boston, MA: Alyn \& Bacon.

[13] NORRIS, D.F., 2007. Current issues and trends in e-government research. Hershey, Pa: IGI Global.

[14] PETER, J., RYAN, M., 1976. An investigation of Perceived Risk at the Brand Level, Journal of Marketing Research, pp.184-188.

[15] PwC, 2015. Paying Taxes 2015: The global picture. United Kingdom: PwC.

[16] VENKATESH, V., and DAVIS, F.D., 1996. A Model of the Antecedents of perceived Ease of Use: Development and Test, Decision Sciences, 27(3), pp.451-481.

[17] VENKATESH, V., and DAVIS, F.D., 2000. A Theoretical Extension of the Technology Acceptance Model: Four Longitudinal Field Studies, Management Science, 46(2), pp. 186-204. 